\title{
Upper eyelid juvenile xanthogranuloma: a case report
}

\author{
Xantogranuloma juvenil em pálpebra superior: relato de caso
}

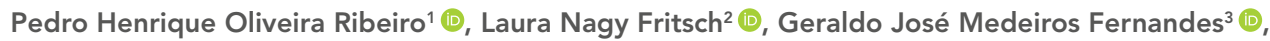
Adriano Macedo de Oliveira ${ }^{4}$ (D), Flávia Beatriz de Andrade Oliveira Ribeiro ${ }^{5}$

Faculdade de Medicina, Universidade Federal de Alfenas, Alfenas, MG, Brazil ${ }^{2}$ Curso Acadêmico de Medicina, Faculdade de Medicina, Universidade Federal de Alfenas, Alfenas, MG, Brazil ${ }^{3}$ Departamento de Anatomia, Universidade José do Rosário Vellano, Alfenas, MG, Brazil. ${ }^{4}$ Departamento de Patologia, Universidade José do Rosário Vellano, Alfenas, MG Brazil. ${ }^{5}$ Departamento de Oftalmologia, Faculdade de Medicina, Universidade Federal de Alfenas, Alfenas, MG, Brazil.

Keywords:

Histiocytosis, Langerhans-cell; Xanthogranuloma, juvenile; Histiocytosis; Eyelid neoplasms

Descritores:

Histiocitose de células não Langerhans; Xantogranuloma juvenil; Histiocitose; Neoplasias palpebrais

Received on: Feb 1, 2021

Accepted on: May 1, 2021

Corresponding author: Pedro Henrique Oliveira Ribeiro Rua Juscelino Barbosa, 885, Apartamento 501. CEP 37130-167. Alfenas, Minas Gerais, Brazil. E-mail: phoribeiro7@gmail.com

Instituition: Universidade Federal de Alfenas (UNIFAL-MG)

Funding: Own funding.

Conflict of interest: There is no conflict of interest.

Financial support: There is no financial support to this article.

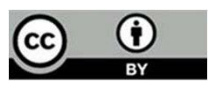

Copyright (C2021

\section{ABSTRACT}

Juvenile xanthogranuloma is a rare benign non-Langerhans cell histiocytosis. Clinical manifestation usually occurs up to the age of 2 years, with yellowish papules and variable clinical progression. Approximately $0.75 \%$ of patients had systemic involvement and $0.25 \%$, ocular alterations. The purpose of this report is to describe a case of a preschool 2-year-old female patient, with nodules in the upper right eyelid, 0.5-cm wide, with well-defined edges, an uncertain date of onset, a stable growth for 6 months, with no inflammatory signs, pruritus, pain, bleeding, or other similar lesions in the body. No further changes were observed in the physical examination. Histopathological examination of the specimen showed a skin lesion with histiocytoid, spindle-shaped cells and xanthomized cells, inflammatory infiltrate and numerous Touton giant cells. The result was compatible with diagnosis of juvenile xanthogranuloma. Therefore, the importance of including juvenile xanthogranuloma in the differential diagnosis of eyelid lesions is emphasized, especially in children.

\section{RESUMO}

O xantogranuloma juvenil é uma patologia histiocítica benigna rara. A manifestação clínica ocorre geralmente até os 2 anos de idade com pápulas amareladas e evolução clínica variável. Cerca de $0,75 \%$ dos pacientes apresentaram comprometimento sistêmico e 0,25\%, comprometimento ocular. 0 objetivo deste relato é descrever o caso de uma pré-escolar de 2 anos do sexo feminino, com nodulação em pálpebra superior direita, $0,5 \mathrm{~cm}$ de base e bordos bem definidos, data de início não estimada, mas crescimento estável há 6 meses, sem sinais flogísticos, prurido, dor, sangramentos ou outras lesões similares no corpo. Sem mais alterações ao exame físico. A análise histopatológica da peça evidenciou lesão cutânea com células histiocitoides, fusiformes e outras xantomizadas; infiltrado inflamatório de permeio e numerosas células gigantes do tipo Touton, resultado compatível com o diagnóstico de xantogranuloma juvenil. Assim, ressalta-se a importância da inclusão do xantogranuloma juvenil no diagnóstico diferencial de lesões palpebrais, especialmente em crianças. 


\section{INTRODUCTION}

Juvenile xanthogranuloma (JXG) is a proliferative disease included in the group of non-Langerhans histiocytosis (NLH) that mostly affects infants and children, and it is congenital in 40 to $70 \%$ of cases. ${ }^{(1)}$

Its manifestation occurs mainly on the skin, with a single typically reddish-yellow papule, with a soft consistency that frequently turns into a solid tumor. ${ }^{(1)}$ The yellowish tone that defines xanthodermatoses is due to the material accumulated in the tissue, composed mainly of cholesterol and triglycerides, elastin and bilirubin..$^{(2)}$

Although benign, it can present some extracutaneous manifestations, such as muscular, pulmonary, hepatic, testicular, splenic, renal involvement, as well as in the central nervous system. ${ }^{(3)}$ Unfortunately, literature data are scarce. About $0.75 \%$ of patients presented systemic involvement, and in $0.25 \%$ there was an ocular lesion. The three main risk factors for this condition are age $\leq 2$ years, cutaneous micronodular form (lesions $\leq 10 \mathrm{~mm}$ ), and multiple skin lesions (approximately 5\% of patients). ${ }^{(1)}$

The clinical presentation helps making diagnosis. Due to the association between JXG and juvenile chronic myeloid leukemia, especially if the patient has neurofibromatosis-1 (NF1), a detailed history of NF1 family history must be taken. ${ }^{(3)}$

Biopsy confirms the diagnosis, revealing the accumulation of atypical histiocytes with eosinophils, lymphocytes, and dispersed foam cells. In $85 \%$ of cases, Touton giant cells are found. Immunohistochemistry is usually negative for S-100 and positive for CD68, factor XIIIa and anti-CD4, ${ }^{(4)}$ a fact that helps differentiating JXG from other Langerhans cell histiocytosis. ${ }^{(3)}$

Most lesions resolve spontaneously within 3 to 6 years. For aesthetic or diagnostic reasons, some can be excised before this period. The use of topical or systemic corticosteroids for intraocular or palpebral lesions is usually reserved for situations of glaucoma or hyphema. ${ }^{(3)}$

The purpose of this case report is to describe a rare case of palpebral JXG in a child, and to enhance reports in the literature, given its clinical importance.

\section{CASE REPORT}

A preschool 2-year-old female patient was taken to the ophthalmology service for evaluation of a nodule in the right upper eyelid, measuring $0.5 \mathrm{~cm}$, with well-defined edges. The guardians denied association with inflammatory signs, pruritus, pain, bleeding, and other similar lesion in the body. The date of onset of lesion was unknown, but they reported the lesion remained stable for the last 6 months.

On physical examination, a papule was observed on the right upper eyelid, about $0.5 \mathrm{~cm}$, with no telangiectasia or pigmentation, regular borders and a brownish surface (Figure 1). The child has a Fitzpatrick phototype II skin. No other abnormalities were observed on examination of the right lower eyelid and left eyelids. No injuries were found in other parts of the body. In the ophthalmological examination, visual acuity was 20/20 in both eyes. The cornea was transparent and unchanged. Iris also did not show any alterations, as well as fundoscopy. The procedure for removing the lesion was performed 6 months after the first consultation at the ophthalmology service, without complications. The excision was successful, with margins free of involvement. After a 6-month follow-up, there was no recurrence of the ocular lesion or manifestations of JXG in other regions of the body.

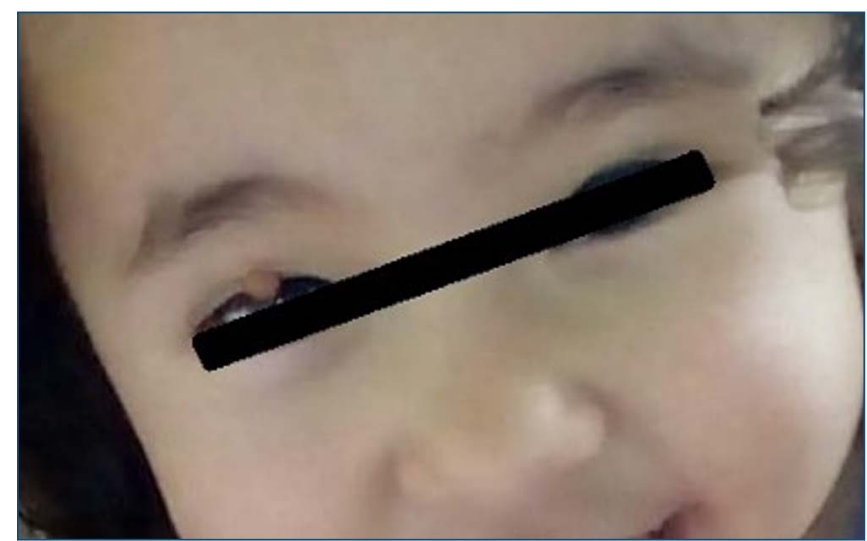

Figure 1. Right upper eyelid xanthogranuloma.

Histopathological analysis of the specimen revealed a $0.5 \times 0.3 \mathrm{~cm}$ polypoid skin lesion, formed by histiocytoid, spindle and other xanthomized cells, with sparse inflammatory infiltrate among numerous Touton giant cells, and rare mitotic figures. Positive CD68 immunohistochemical expression, and negative for desmin, myogenin, and SOX1O. The result is compatible with diagnosis of JXG (Figure 2).

\section{DISCUSSION}

Xanthogranuloma presents as a small single or multiple yellowish or rosacea papule. It can be congenital or acquired. The clinical evolution varies and, in most cases, it is asymptomatic, or progresses with complete regression of the lesion, as described in some cases. There may be systemic involvement and risk of intraocular complications. ${ }^{(1)}$ 


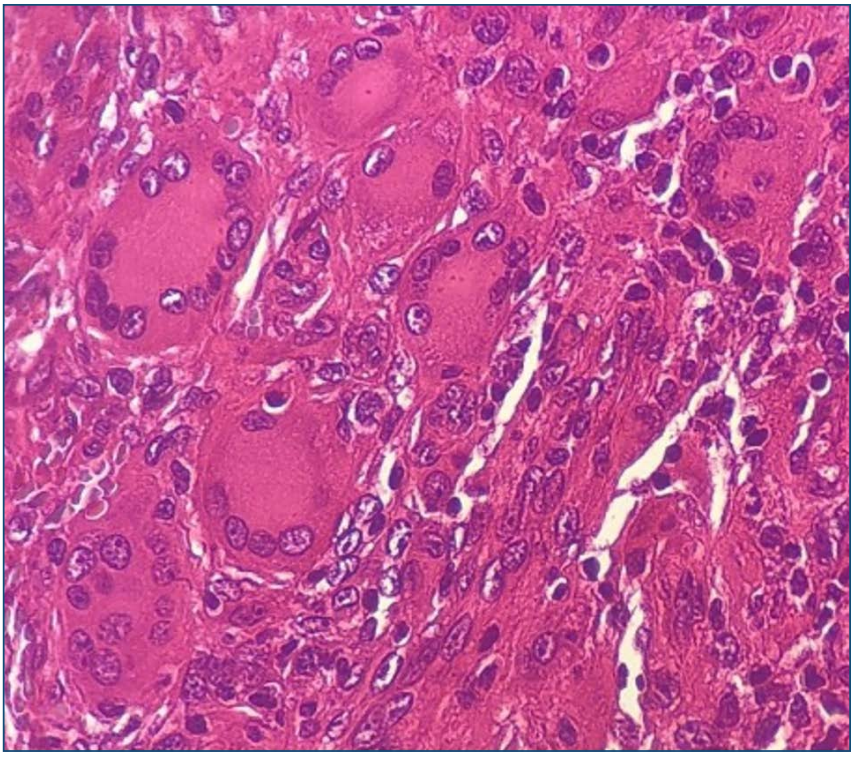

Figure 2. Microphotography showing Touton giant cells, characteristic of juvenile xanthogranuloma.

The definitive diagnosis of JXG is histopathological. It shows a diffuse histiocytic infiltrate, with five distinct cell types (vacuolated, xanthomatized, oncocytic, spindle-shaped and with irregular borders), foamy macrophages and Touton giant cells, characteristic of JXG and present in about $85 \%$ of cases. ${ }^{(5)}$ It is not an encapsulated lesion. ${ }^{(6)}$ Immunohistochemistry is usually reactive for CD68, factor XIIIa and anti-CD4 markers. ${ }^{(7)}$

Dermoscopy of the lesion can assist in diagnosis, presenting a yellow-orange base, with a halo characterizing the "setting sun" pattern, fine branched centripetal vessels, and pale-yellow clouds, which represents the typical histiocytic infiltrate of JXG. ${ }^{(8)}$

Juvenile xanthogranuloma occurs in different forms on the eyelid and eye. A review of the literature revealed the description of 15 cases of JXG with ocular and eyelid involvement, 11 in females, three in males, and one case in which sex was not reported. Several clinical manifestations were observed, with four cases of eyelid masses caused by JXG. Descriptions of secondary glaucoma, hyphema, uveitis, and involvement of the optic disc and retina were found, showing the broad spectrum of ophthalmic manifestations of the disease. The treatments for each case varied, including excision of eyelid lesions, enucleation of the eyeball in cases in which it was not possible to differentiate JXG from a neoplastic mass, and the use of corticosteroids to decrease the size of lesions. ${ }^{(9)}$

Ocular and adnexal manifestations of JXG can be diverse. The most frequent in a series of 30 cases was ocular redness (52\% of cases), followed by hyphema. There was also the presentation of JXG as an iris, conjunctival or periocular mass, heterochromia, and impaired visual acuity. The most affected sites of the eye were the iris (70\% of cases), conjunctiva, choroid, and orbit. In only two cases the eyelids were affected. The mean basal diameter of the eyelid nodules was $18 \mathrm{~mm}$, with an average thickness of $16 \mathrm{~mm}$. Both nodules regressed after 15 months of follow-up, with surgical procedure being chosen for one and observation for the other. Eyelid involvement is rare and has a better prognosis than iris JXG. ${ }^{(10)}$

Given the above, the importance of including JXG in the differential diagnosis of eyelid lesions is emphasized, especially in children. It is a rare disease, with a wide spectrum of clinical manifestations, and demands evaluation for intraocular and systemic involvement, as well as investigation for possible recurrence and manifestations as other skin nodules.

\section{REFERENCES}

1. Samuelov L, Kinori M, Chamlin SL, Wagner A, Kenner-Bell BM, Paller AS, et al. Risk of intraocular and other extracutaneous involvement in patients with cutaneous juvenile xanthogranuloma. Pediatr Dermatol. 2018;35(3):329-35.

2. Frew JW, Murrell DF, Haber RM. Fifty shades of yellow: a review of the xanthodermatoses. Int J Dermatol. 2015;54(10):1109-23.

3. Rana A, de Waal Malefyt S. An infant who has dome-shaped papules. Pediatr Rev. 2012;33(2):86-8.

4. So N, Liu R, Hogeling M. Juvenile xanthogranulomas: Examining single, multiple, and extracutaneous presentations. Pediatr Dermatol. 2020;37(4):637-44.

5. Chang MW. Update on juvenile xanthogranuloma: unusual cutaneous and systemic variants. Semin Cutan Med Surg. 1999;18(3):195-205.

6. Höck M, Zelger B, Schweigmann G, Brunner B, Zelger B, Kropshofer G, et al. The various clinical spectra of juvenile xanthogranuloma: imaging for two case reports and review of the literature. BMC Pediatr. 2019;19(1):128.

7. Pajaziti L, Hapçiu SR, Pajaziti A. Juvenile xanthogranuloma: a case report and review of the literature. BMC Res Notes. 2014;7:174.

8. Fernandes JR, Fernandes EL, Steiner D. Aspectos dermatoscópicos do xantogranuloma juvenil com múltiplas lesões. Surg Cosmet Dermatol. 2016;7(4):332-8

9. Hassan A, Talib N, Adzman S, Hussein A. Eyelid juvenile xanthogranuloma: a case report and literature review. Cureus. 2019;11(6):e5008.

10. Samara WA, Khoo CT, Say EA, Saktanasate J, Eagle RC Jr, Shields JA, et al. Juvenile Xanthogranuloma Involving the Eye and Ocular Adnexa: Tumor Control, Visual Outcomes, and Globe Salvage in 30 Patients. Ophthalmology. 2015;122(10):2130-8. 